\title{
Performance evaluation of a novel anaerobic digestion operation process for treating high-solids content chicken manure: Effect of reduction of the hydraulic retention time at a constant organic loading rate
}

\author{
Wanqin Zhang ${ }^{\mathrm{a}, \mathrm{b}, *}$, Qianqian Lang ${ }^{\mathrm{c}}$, Zhendong Pan ${ }^{\mathrm{d}}$, Yingqing Jiang ${ }^{\mathrm{d}}$, Jan Liebetrau ${ }^{\mathrm{d}}$, Michael Nelles ${ }^{\mathrm{d}}$, \\ Hongmin Dong ${ }^{\mathrm{a}}$, Renjie Dong ${ }^{\mathrm{b}}$ \\ a Institute of Environment and Sustainable Development in Agriculture, Chinese Academy of Agricultural Sciences, Beijing 100081, PR China \\ ${ }^{\mathrm{b}}$ College of Engineering (Biomass Engineering Center), China Agricultural University, Beijing 100083, PR China \\ ${ }^{\mathrm{c}}$ Research Center for Eco-Environmental Sciences, Chinese Academy of Sciences, 18 Shuangqing Road, Beijing 100085, PR China \\ ${ }^{\mathrm{d}}$ Department of Biochemical Conversion, Deutsches Biomasseforschungszentrum gemeinnützige GmbH (DBFZ), Leipzig 04347, Germany
}

\section{A R T I C L E I N F O}

\section{Article history:}

Received 4 June 2016

Revised 15 March 2017

Accepted 20 March 2017

Available online 28 March 2017

\section{Keywords}

Anaerobic digestion

Chicken manure

Ammonia inhibition

Hydraulic retention time

Kinetics

Biomass yield

\begin{abstract}
A B S T R A C T
A novel feeding strategy was adopted in this study and the effect of reduction in hydraulic retention time (HRT) on the anaerobic digestion of chicken manure (CM) with a constant organic loading rate of $6.0 \mathrm{gVS} / \mathrm{L} / \mathrm{d}$ was investigated. The lab-scale CSTR was operated at $38^{\circ} \mathrm{C}$ and $\mathrm{HRT}_{\mathrm{CM}}$ was reduced from 52 days to 5 days. At $\mathrm{HRT}_{\mathrm{CM}}$ of 20-45 days, the reactor was relatively stable in terms of the volumetric biogas production rates and specific biogas production (SBP), which were $2.2-2.4 \mathrm{~L} / \mathrm{L} / \mathrm{d}$ and $338.3-418.7 \mathrm{~mL} / \mathrm{gVS}_{\text {added }}$, respectively. However, process instability and VFA accumulation occurred when the $\mathrm{HRT}_{\mathrm{CM}}$ was reduced to 10 days due to excess microbes washout. The reduction in $\mathrm{HRT}_{\mathrm{CM}}$ to 5 days caused SBP to decrease to $198.7 \mathrm{~mL} / \mathrm{gVS}_{\text {added }}$ and the acetic acid content to exceed $6000 \mathrm{mg} / \mathrm{L}$. The biomass balance model showed that the biomass concentration at $\mathrm{HRT}_{\mathrm{CM}}$ of $20-52$ days (0.473-0.615 gVSS/L) was notably higher than that at $\mathrm{HRT}_{\mathrm{CM}}$ of $5-10$ days $(0.173 \mathrm{gVSS} / \mathrm{L})$.
\end{abstract}

(c) 2017 Elsevier Ltd. All rights reserved.

\section{Introduction}

With the development of large-scale intensive chicken farming, large amounts of wastes are produced in China yearly. Given that the organic matter in chicken manure (CM) is easily biodegradable, methane fermentation is considered an alternative method to minimize waste and recover bioenergy (Nie et al., 2015; Niu et al., 2013). To improve the utilization efficiency and reduce the investment costs of biogas plants, a relatively high organic loading rate (OLR) is often adopted (Dalkilic and Ugurlu, 2015; Zhang et al., 2014). However, CM is rich in nitrogen, and excessive ammonia produced by hydrolysis at high OLR exerts a toxic and inhibitory effect on microbial activity and leads to failure. Volatile fatty acids (VFA) accumulation mostly occurred as a result of ammonia inhibition (Chen et al., 2008b). Niu et al. (2013) reported that the biogas yield from the mesophilic methane fermentation of CM alone was decreased by $25.0 \%$, and VFA concentration reached $15,000 \mathrm{mg} / \mathrm{L}$

\footnotetext{
* Corresponding author at: Institute of Environment and Sustainable Development in Agriculture, Chinese Academy of Agricultural Sciences, Beijing 100081, PR China.

E-mail address: zhang394982409@126.com (W. Zhang).
}

with a total ammonia nitrogen (TAN) of $10,000 \mathrm{mg} / \mathrm{L}$. For a mesophilic-thermophilic two-stage anaerobic system, the VFA concentrations in the acidogenic reactor increased to $16,964 \mathrm{mg} / \mathrm{L}$ and the biogas production rate decreased from $554 \mathrm{~mL} / \mathrm{gVS}_{\text {added }}$ to $426 \mathrm{~mL} / \mathrm{gVS}_{\text {added }}$ with TS (total solids) loading of $8.25 \%$. A maximum bearing OLR of $6.0 \mathrm{gVS} / \mathrm{L} / \mathrm{d}$ was reported by Nie et al. (2015), who found that the biogas yield for mesophilic fermentation of CM decreased from $350 \mathrm{~mL} / \mathrm{gVS}_{\text {added }}$ to $270 \mathrm{~mL} / \mathrm{gVS}_{\text {added }}$ with a TAN of $6900 \mathrm{mg} / \mathrm{L}$. Hence, to avoid inhibition of ammonia and maintain operation stability, the OLR should be lower than $6.0 \mathrm{gVS} / \mathrm{L} / \mathrm{d}$ (Nie et al., 2015).

To prevent the inhibition of ammonia for biogas plants treating $\mathrm{CM}$ at high OLR, diluting the substrate by adding water is an effective method. However, adding water to the substrate shortens the hydraulic retention time (HRT). For a large-scale biogas plant, a short HRT is desired to reduce digester volume, investment costs (Schmidt et al., 2014) and improve net electrical energy recovery (Di Maria et al., 2015). In addition, the HRT as a key parameter in biogas processes that influences the anaerobic digestion (AD) operation stability, biogas production, biomass concentration and kinetic model parameters (Dareioti and Kornaros, 2014; Kukkonen, 2014; Schmidt et al., 2014). Dareioti and Kornaros 
(2014) pointed out that the methanogenic reactor shows better stability with HRT of 25 days than that with 20 days, and significant accumulation of VFA occurs at HRT of 20 days. Besides, a short HRT can cause the washout of microbes when the generation times of the microorganisms are shorter than the HRT, which leading to failure of the AD system (Schmidt et al., 2014). Microorganisms (acidogens, acetogens and methanogens) involved in AD process have a distinct generation time (Güelfo et al., 2013; Gerber and Span, 2008; Jaxybayeva et al., 2014). For acidogenesis and acetogenesis, the acid-forming bacteria and acetogenic bacteria have a minimum doubling time of about $30 \mathrm{~min}$ and 1.5-4.0 days, respectively (Gerber and Span, 2008; Mosey, 1983). For methanogenesis, hydrogenotrophic methanogens show a short minimum doubling time of $1 \mathrm{~h}$ than acetoclastic methanogens (2-3 d) (Gerber and Span, 2008; Thauer et al., 2008).

As previously reported, for a continuous stirred tank reactor (CSTR), a minimum HRT of 10-25 days is obligatory to prevent the washout of slow-growing methanogens (Güelfo et al., 2013; Schmidt et al., 2014). Schmidt et al. (2014) reported that notable deterioration observed for a CSTR that treats simulated thin stillage as the HRT is reduced to 3 days because of the excessive washout of methanogens. Hence, maintain appropriate microorganism concentration and determine the biomass content are important for $\mathrm{AD}$ system to execute steadily. In the $\mathrm{AD}$ process for treating organic wastewater, biomass content is usually measured as volatile suspended solid (VSS) (Guo et al., 2013). Nevertheless, directly measuring the content of VSS to indicate the biomass concentration for a non-soluble waste e.g. manure based digester feedstock is unscientific (Ghaly et al., 2000). So, some kinetic models, such as the substrate mass balance model, the biomass balance model, have been introduced to calculate the biomass content and evaluate the performance of digesters for treating different types of nonsoluble substrates (food waste, pig manure, etc.) (Borja et al., 2002; Guo et al., 2013; Wei et al., 2014; Zhang et al., 2015).

Although some research has been done focusing on the influence of HRT on the performance of AD process, commonly in the previous studies, the reduce in HRT coupled with the increase of OLR (Climenhaga and Banks, 2008; Dareioti and Kornaros, 2014; Di Maria et al., 2015; Qiang et al., 2012). For example, in the anaerobic co-digestion of sludge and FVW (fruit and vegetable waste) system, the OLR increased from $1.46 \mathrm{gVS} / \mathrm{L} / \mathrm{d}$ to $2.80 \mathrm{gVS} / \mathrm{L} / \mathrm{d}$ as HRT reduced from 14 days to 10 days (Di Maria et al., 2015). In addition, the noticeable increase in biogas yield caused by the reduced HRT was also a consequence of the increased OLR. Differently from previous research, in this study, a novel operation strategy was adopted. That is, the reactor was feed with stable mass of chicken manure per day to keep a constant OLR (basis on VS), but the HRT decreased gradually by recycle the stripped biogas slurry and adding water. Based on this new feeding strategy, one side, the knowledge about how reduced HRT affects the AD performance is limited. On the other side, there is also no kinetic analysis has been reported on the substrate utilization and the change in biomass concentration the AD of CM with reduced HRT. Hence, the main objective of this study was to identify whether the reduce in HRT relaxed the inhibition of ammonia at a constant high OLR. To clarify these, effect of a decreasing HRT on biogas yield, gas composition, TAN, FAN, VFA and kinetic model parameters was investigated.

\section{Material and methods}

\subsection{Materials and digesters}

Fresh chicken manure (CM) was collected from a biogas plant using CM as feedstock, in Chemnitz, Germany. The CM was stored in a sealed-plastic barrel and flushed with $100 \%$ pure nitrogen gas, then kept in a cooling room at $4{ }^{\circ} \mathrm{C}$. The original inoculum to start up the fermenter was taken from another digester for treating cattle manure. The biogas production potential of CM was determined by Automatic biogas Potential Test System (AMPTS II, Bioprocess control, Sweden) according to German standard VDI 4630 (VDI, 2006). The characteristics of $\mathrm{CM}$ and inoculum are shown in Table 1.

A lab-scale continuous stirred tank reactor (CSTR) with a working volume of $10 \mathrm{~L}$ (total $15 \mathrm{~L}$ ) was used in this study. The feeding port of the CSTR was sealed with a rubber bung, and the sealed tube with tube bottom was submerged in the fermentation medium. A stirrer with a stirring speed of $100 \mathrm{rpm}$ was fixed in the middle of the top plate. The reactor was warmed by circulating water supplied by a heating circulator (Proline P8, Lauda DR. R. Wobser GmbH \& Co. KG, Germany) and it was maintained at $(38 \pm 1)^{\circ} \mathrm{C}$.

\subsection{Experimental procedure}

The digester was commissioned in January 2011. In the initial period of this digester, around $9 \mathrm{~L}$ inoculum (digested cattle manure) was added to start-up this digester, and the initial OLR was 2.2 $\mathrm{gVS}_{\mathrm{CM}} / \mathrm{L} / \mathrm{d}$. Hence, the digester had been operated for more than 1280 days before this study began using CM as the feedstock. In this study, the digestate was drawn out through an outlet port at the bottom of the reactor, and the new mixed substrate was fed into the digester via the feeding port once daily. Biogas volume was monitored daily by a wet-type gas flow meter (Ritter TG 05, Dr. -Ing. Ritter Apparatebau GmbH \& Co. KG, Germany) and the biogas production was corrected to value at standard temperature and pressure $\left(0^{\circ} \mathrm{C}, 101.325 \mathrm{kPa}\right)$. The digestate was collected daily in a covered tank at room temperature (around $20^{\circ} \mathrm{C}$ ). Once a week, the digestate was centrifuged at $10,000 \mathrm{rpm}$ and $10^{\circ} \mathrm{C}$ for 10 min (Sorvall ${ }^{\mathrm{TM}} \mathrm{RC} 6$ Plus, Thermo Scientific, USA). By centrifugation, around $97 \%$ solids fraction was separated from the digestate, and the total solids (TS) content in liquid fraction was around 3\% (date not shown). After solid-liquid separation, the solids fraction was dried to a constant weight at $105^{\circ} \mathrm{C}$, then ground to $2 \mathrm{~mm}$ (SM 200, Retsch GmbH, Germany), which was used to maintain the TS concentration of the feed mixture (feeding TS $\approx 14 \%$ ). In order to avoid the ammonia inhibition, the liquid fraction was stripped to remove ammonia firstly at $80^{\circ} \mathrm{C}$ and $450 \mathrm{mbar}$

Table 1

Characteristics of chicken manure (CM) and seed sludge (SS) used in the experiment.

\begin{tabular}{llll}
\hline Parameters & CM (this study) & $\begin{array}{l}\text { CM (Niu et al., } \\
\text { 2013) }\end{array}$ & SS \\
\hline TS (\% FM) & $47.3 \pm 0.4$ & $11.2 \pm 0.5$ & $4.1 \pm 0.3$ \\
VS (\% FM) & $31.2 \pm 0.3$ & $8.3 \pm 0.8$ & $3.2 \pm 0.1$ \\
VS (\% TS) & $65.5 \pm 0.2$ & 73.8 & $78.1 \pm 2.7$ \\
pH & $8.07 \pm 0.02$ & & $7.36 \pm 0.06$ \\
TAN (mg/kg FM) & $4415.5 \pm 216.0$ & $3850 \pm 200$ & $526.3 \pm 22.9$ \\
FAN (mg/kg FM) & $1094.1 \pm 88.2$ & & $15.0 \pm 2.1$ \\
TIC (mg CaCO3/kgFM) & $48090.5 \pm 7199$ & & $6775 \pm 104$ \\
VFA (mg CH ${ }_{3}$ COOH/kgFM) & $26632.5 \pm 3312$ & & $1419 \pm 57$ \\
C (\% TS) & $33.08 \pm 0.21$ & $35.2 \pm 0.45$ & \\
N (\% TS) & $4.91 \pm 0.13$ & $5.44 \pm 0.24$ & \\
H (\% TS) & $4.28 \pm 0.09$ & $4.83 \pm 0.05$ & \\
S (\% TS) & $0.83 \pm 0.07$ & $0.84 \pm 0.10$ & \\
O (\% TS) & $26.64 \pm 0.13$ & $30.12 \pm 0.18$ & \\
C/N & 6.74 & 6.47 & \\
Biogas production & 422.4 & & \\
$\quad$ potential (mL/gVS) & & & \\
\hline
\end{tabular}

TS: total solids, FM: fresh matter, VS: volatile solids. TAN: total ammonia nitrogen, FAN: free ammonia nitrogen, TIC: total inorganic carbon and VFA: volatile fatty acids, Biogas production potential was achieved by BMP test. 
according to the method described by Nie et al. (2015), and around $80 \%$ ammonia was removed in this process (ammonia concentration decreased from around $6000 \mathrm{mg} / \mathrm{L}$ to less than $1000 \mathrm{mg} / \mathrm{L}$ ), then the stripped liquid was used to adjust the HRT. In this study, the HTR was defined as $\mathrm{HRT}_{\mathrm{CM}}$ (Hydraulic retention time of chicken manure) and $\mathrm{HRT}_{\text {total }}$. The daily feed of chicken manure (basis on VS) was constant and the OLR was kept at $6.0 \mathrm{gVS}_{\mathrm{CM}} / \mathrm{L} / \mathrm{d}$. CM was diluted with different amount of distilled water to reduce the $\mathrm{HRT}_{\mathrm{CM}}$ in different periods and therefore the VS concentration in the substrate was reduced with decreasing $\mathrm{HRT}_{\mathrm{CM}}$. By this strategy, the $\mathrm{HRT}_{\mathrm{CM}}$ was decreased from 52 days to $45,40,30,20$, and 5 days in the CSTR. The detail operational process diagram is shown in Fig. 1 and Table 2. As shown in Fig. 1, the feedstock included four parts, such as fresh $\mathrm{CM}$, distilled water, N-stripped biogas slurry, and the dried solids fraction of digestate. All fractions were used in different ratios according to the need to prepare the feed mixture (Table 2). The $\mathrm{HRT}_{\mathrm{CM}}$ and $\mathrm{HRT}_{\text {total }}$ were calculated using Eqs. (1) and (2):

$H R T_{C M}=\frac{\mathrm{V}_{\text {working }}}{\text { the mass of fresh } \mathrm{CM}+\text { distilled water }}$

$$
\begin{aligned}
& H R T_{\text {total }} \\
& \quad=\frac{\mathrm{V}_{\text {working }}}{\text { fresh } \mathrm{CM}+\text { distilled water }+X_{i} \times(N-\text { removed biogas slurry })}
\end{aligned}
$$

where the $H R T_{C M}$ means the HRT of chicken manure, which is designed to decrease from 52 to 5 days by adding water. $H R T_{\text {total }}$ changes coupled with the decrease of $H R T_{C M}$. The mass of fresh $\mathrm{CM}$ is constant to keep a constant OLR (based on VS). $X_{i}$ means the ammonia removal efficiency (\%) at different periods.

\subsection{Analytical methods and calculation}

TS and volatile solids (VS) were determined using the standard methods (APHA, 2005). $\mathrm{pH}$ was determined using a digital $\mathrm{pH}$ meter (pH3310, WTW Wissenschaftlich-Technische Werkstätten $\mathrm{GmbH}$, Germany). TKN was measured with a basic Kjeldahl distillation system (Vapodest 10sn, C. Gerhardt GmbH \& Co. KG, Germany). The total inorganic carbon (TIC) and total VFA contents, expressed as acetate equivalent $(\mathrm{mg} / \mathrm{L})$ were analyzed by titration with $0.1 \mathrm{~N} \mathrm{H}_{2} \mathrm{SO}_{4}$ to the endpoints of $\mathrm{pH} \mathrm{5.0,} \mathrm{and} 4.4$ using a T90 titrator (Mettler-Toledo International Inc., Switzerland) (Nie et al., 2015). Air-dried manure sample was used for elemental analysis (C, H, N, S, O) by an elemental analyzer (Vario EL/micro cube, Germany) (Otero et al., 2011). Single volatile fatty acids (acetic, propionic, iso-butyric, n-butyric, iso-valeric, and n-valeric acids) concentrations were quantified using a gas chromatograph (GC) (Agilent 7890A, Agilent Technologies, USA) equipped with a HS110 automatic headspace sampler (Perkin Elmer, USA) and a flame ionization detector (FID) using nitrogen $\left(\mathrm{N}_{2}\right)$ as the carrier gas following the previously described method (Nie et al., 2015; Schmidt et al., 2014). Gas composition $\left(\mathrm{CH}_{4}, \mathrm{CO}_{2}, \mathrm{O}_{2}\right.$ and $\left.\mathrm{H}_{2} \mathrm{~S}\right)$ was measured by a portable gas analyzer (ATEX BM5000, Analytische Systeme und Componenten $\mathrm{GmbH}$, Germany). Total ammonia nitrogen (TAN) was analyzed by a DR3900 spectrophotometer (Hach Lange GmbH, Germany) using the Nessler method. The free ammonia nitrogen (FAN) concentration was calculated using Eq. (3) (Anthonisen et al., 1976).

$$
\begin{aligned}
& \mathrm{FAN}=\frac{\mathrm{TAN}}{1+10^{(p \mathrm{Ka}-p \mathrm{H})}} \\
& p \mathrm{Ka}=0.09018+\frac{2729.92}{\mathrm{~T}+273.15}
\end{aligned}
$$

T: the temperature $\left({ }^{\circ} \mathrm{C}\right)$

The effects of TAN on specific biogas production (SBP) and VFA were described and calculated using the extended Boltzmann equation:

$$
\mathrm{Y}=A_{2}+\frac{A_{1}-A_{2}}{1+\exp \left(\frac{x-x_{0}}{d x}\right)}
$$

where $A_{1}$ represents the initial value of SBP or VFA concentration, $A_{2}$ represents the final value of SBP or VFA concentration, $x_{0}$ represents $50 \%$ inhibition value and dx means TAN concentration derivative (the change in $\mathrm{X}$ corresponding to the most significant change in $\mathrm{Y}$ values).

\section{Results and discussion}

\subsection{Performance of methane fermentation at period I}

The performance in terms of volumetric biogas production rates (VBPR), specific biogas production (SBP), gas composition, $\mathrm{pH}, \mathrm{VFA} /$ TIC ratio, TAN, FAN and VFA concentration are shown in Figs. 2-4. According to the performance, the period I (1-70 d) was divided into two parts (stable and unstable parts).

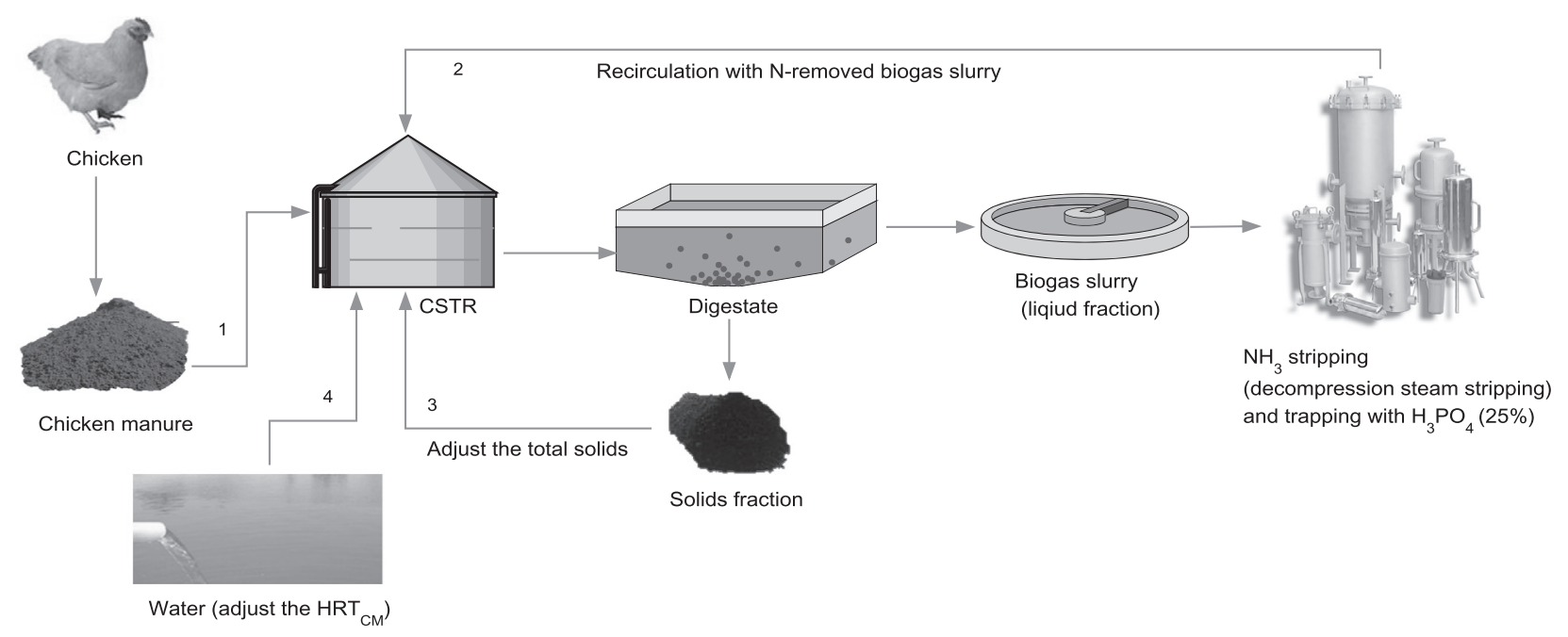

Fig. 1. Process diagram in this study. 
Table 2

Summary of experimental digester operation process.

\begin{tabular}{|c|c|c|c|c|c|c|c|c|c|}
\hline \multirow[t]{2}{*}{ Period (days) } & \multirow[t]{2}{*}{ OLR (gVS/L/d) } & \multirow[t]{2}{*}{$\operatorname{HRT}_{\mathrm{CM}}$ (days) $^{\mathrm{a}}$} & \multirow[t]{2}{*}{$\mathrm{HR}_{\text {Ttotal }}(\text { days })^{\mathrm{b}}$} & \multirow[t]{2}{*}{ N-removal efficiency } & \multicolumn{4}{|c|}{ Mixing substrate (g) } & \multirow[t]{2}{*}{ Working volume (L) } \\
\hline & & & & & $\mathrm{CM}^{\mathrm{C}}$ & Biogas slurry $^{\mathrm{d}}$ & Solids ${ }^{\mathrm{e}}$ & Water $^{\mathrm{f}}$ & \\
\hline $1-70$ & 6.0 & 52 & 15.0 & $80.7 \%$ & 192.3 & 465.4 & 9.0 & 0 & 10 \\
\hline 71-99 & 6.0 & 45 & 13.8 & $79.5 \%$ & 192.3 & 485.7 & 18.0 & 29.9 & 10 \\
\hline $100-133$ & 6.0 & 40 & 12.3 & $81.3 \%$ & 192.3 & 531.0 & 30.8 & 57.7 & 10 \\
\hline $134-161$ & 6.0 & 30 & 9.5 & $83.0 \%$ & 192.3 & 652.7 & 67.0 & 141.0 & 10 \\
\hline $162-193$ & 6.0 & 20 & 6.4 & $80.0 \%$ & 192.3 & 918.3 & 143.2 & 307.7 & 10 \\
\hline $194-226$ & 6.0 & 10 & 3.5 & $79.4 \%$ & 192.3 & 1520.4 & 337.8 & 807.7 & 10 \\
\hline $227-254$ & 6.0 & 5 & 2.2 & $67.8 \%$ & 192.3 & 2000.0 & 598.8 & 1807.7 & 10 \\
\hline
\end{tabular}

a ${ }^{2} \mathrm{HRT}_{\mathrm{CM}}$ was calculated by $10 \mathrm{~L} \times 1000 \mathrm{~g} /(\mathrm{CM}+$ water $)$.

b HRTtotal was calculated according to Eq. (2).

c $\mathrm{CM}$ means chicken manure.

d Biogas slurry means the liquid fraction of digestate and the ammonia inside also has been stripped to lower than $1000 \mathrm{mg} / \mathrm{L}$.

e Solids mean the dried solid fraction of digestate.

${ }^{\mathrm{f}}$ Water means the distill water used to adjust the HRTCM.

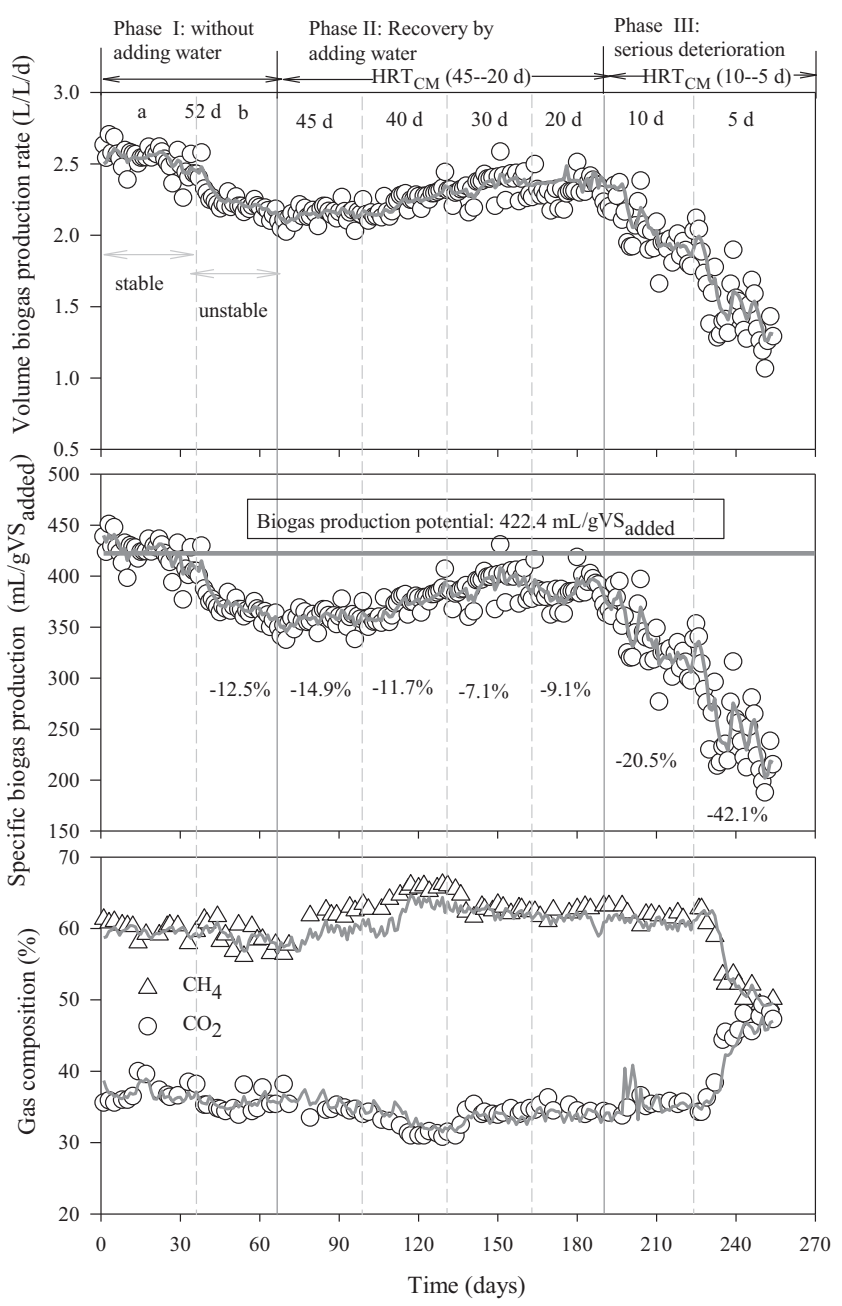

Fig. 2. Effect of $H R T_{C M}$ on volume biogas production rate (VBPR), specific biogas production (SBP) and gas composition.

In the initial phase I-a (days 1-38), the VBPR, SBP, the gas composition, $\mathrm{pH}$ and VFA concentration were stable, indicating that the digester ran well (Figs. 2-4). At days 1-38, the SBP was around $421.7 \mathrm{~mL} / \mathrm{gVS}_{\text {added, }}$, which was similar to the biogas production potential of CM achieved by the batch test $\left(422.4 \mathrm{~mL} / \mathrm{gVS}_{\text {added }}\right)$. This value was compared with the result obtained by Niu et al. (2013), who reported that the SBP of CM is $350-400 \mathrm{~mL} / \mathrm{gVS}_{\text {added }}$ at mesophilic temperature. Dalkılic and Ugurlu (2015) found a higher biogas production rate of $426-554 \mathrm{~mL} / \mathrm{gVS}_{\text {added }}$ from CM

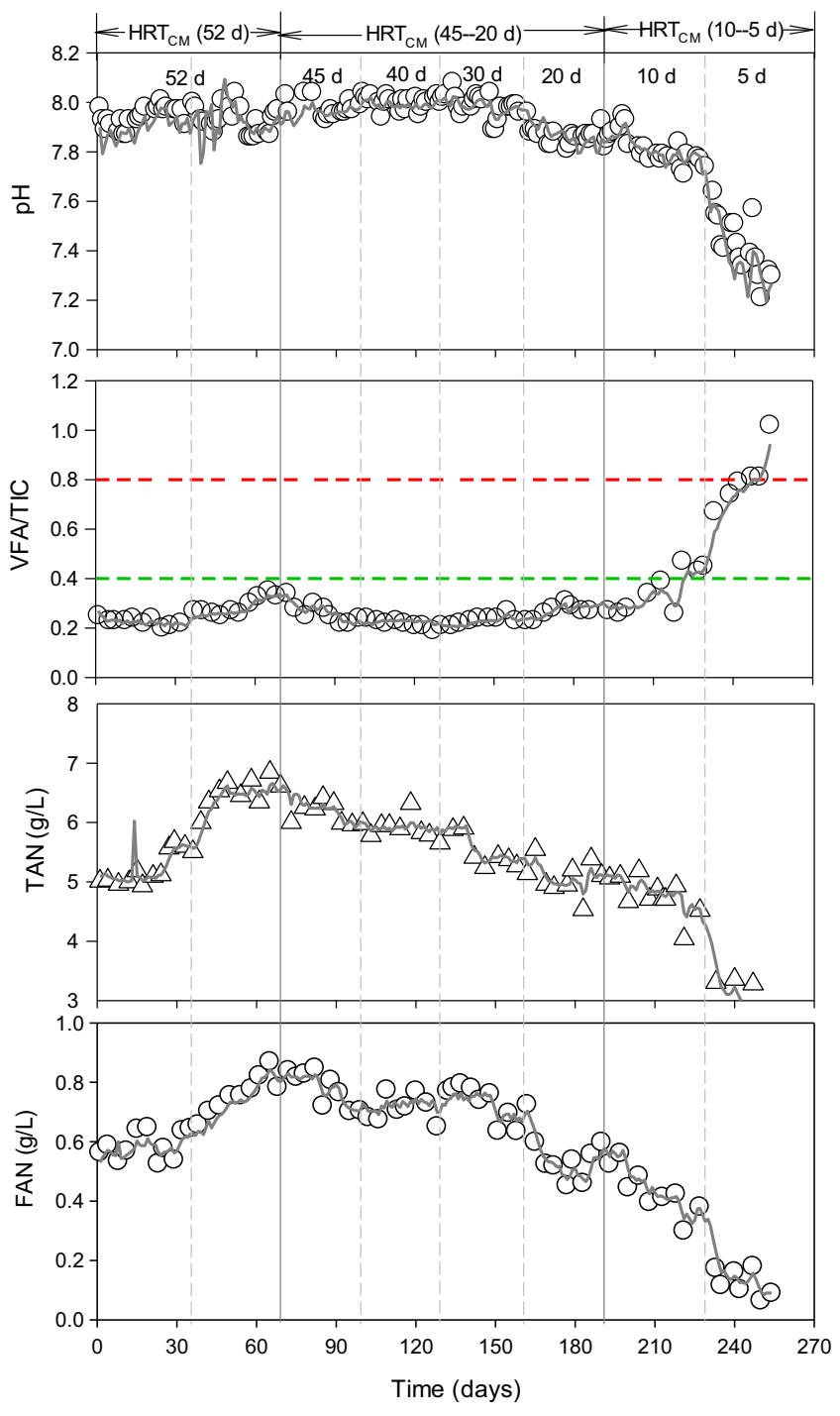

Fig. 3. Effect of $\mathrm{HRT}_{\mathrm{CM}}$ on $\mathrm{pH}, \mathrm{VFA} / \mathrm{TIC}$ ratio and ammonium concentration.

at OLR of 1.9-4.7 g VS/L/d in a mesophilic-thermophilic two stage anaerobic system. The reason for the relatively higher SBP in the study of Dalkilıc and Ugurlu (2015) could be that the two-stage system improved the VS destruction efficiency and reduce the inhibitory effect of TAN. In phase I-a, the $\mathrm{CH}_{4}$ and $\mathrm{CO}_{2}$ concentrations remained at $57.9-66.2 \%$ and $30.8-36.3 \%$, respectively, and the 


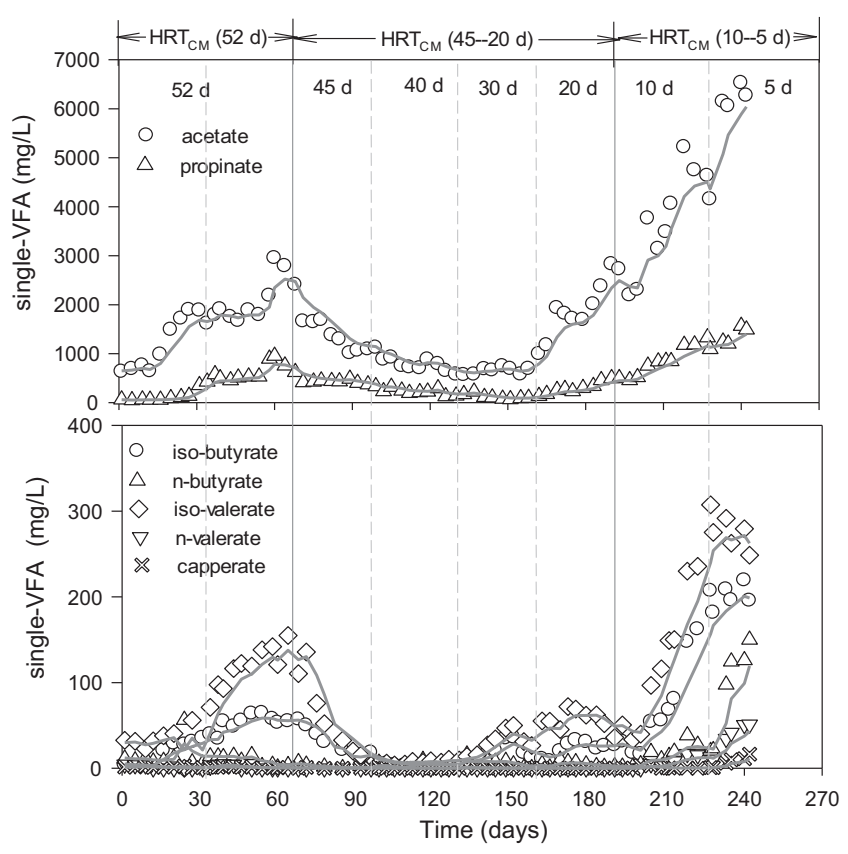

Fig. 4. Effect of $\mathrm{HRT}_{\mathrm{CM}}$ on single-volatile fatty acids.

$\mathrm{CH}_{4}$ content was compared with the values (around 60\%) obtained by Nie et al. (2015) and Niu et al. (2013). In this period, the TAN concentration varied from 5200 to $6400 \mathrm{mg} / \mathrm{L}$, and the VFA was kept below $3000 \mathrm{mg} / \mathrm{L}$. Although TAN concentrations above $3000 \mathrm{mg} / \mathrm{L}$ were considered a risk to reactor stability, no significant inhibition was observed in phase I-a. The phenomena could be explained by that the methanogens could tolerate higher TAN concentration after a long-term acclimation because the digester has run about 1280 days before this study (Yenigün and Demirel, 2013).

However, in phase I-b (days 39-70), the TAN generally climbed to approximately $7000 \mathrm{mg} / \mathrm{L}$. Subsequently, the TVFA/TIC ratio generally rose to the early warning threshold of $0.3-0.4$, indicating the development of digestion instability (Zhang et al., 2015). The concentrations of acetic and propionic acids accumulated to 2900 and $950 \mathrm{mg} / \mathrm{L}$, respectively. Interestingly, for other VFA, only isobutyric and iso-valeric acids, but not $n$-butyric and $n$-valeric acids, were significantly observed. This finding could be explained by the fact that straight-chain VFA are easily degraded than branchedchain VFA during AD (Matthies and Schink, 1992).
The effects of increasing TAN concentration on the SBP and TVFA accumulation were illustrated in Fig. 5. As the VFA accumulated, the SBP of CM generally dropped to $369.7 \mathrm{~mL} / \mathrm{gVS}_{\text {added }}$, compared with the biogas production potential, which was decreased by $12.5 \%$. This indicated that at high OLR of $6.0 \mathrm{~g} \mathrm{VS} / \mathrm{L} / \mathrm{d}$, the recycling of N-removal slurry was not enough for relieving the ammonia accumulation. A novel strategy needed to develop to maintain the operational stability under high constant OLR conditions.

\subsection{Effect of reducing HRT on the performance of digester}

To prevent the inhibition of high concentrations of TAN and maintain a constant OLR of CM, a reasonable amount of water was used to dilute the fresh $\mathrm{CM}$ in phases II and III according to the method recommended by Schmidt et al. (2014). In phase II, the $\mathrm{HRT}_{\mathrm{CM}}$ was gradually reduced to $45,40,30$ and 20 days corresponding to the $\mathrm{HRT}_{\text {total }}$ of $16.4,14.7,11.4$ and 8.1 days, respectively. In this phase, the TAN concentration decreased from 7000 to $4900 \mathrm{mg} / \mathrm{L}$ because of the dilution of water, and the inhibition caused by TAN was slightly alleviated. In terms of the biogas yield, the SBP at $\mathrm{HRT}_{\mathrm{CM}}$ of $45,40,30$ and 20 days was 359.4, 372.9, 392.3 and $383.9 \mathrm{~mL} / \mathrm{gVS}_{\text {added, }}$, respectively, compared with that achieved from phase I-b, which was an improvement of $-2.8 \%, 0.9 \%, 6.1 \%$ and $3.8 \%$, respectively. These suggested that appropriate reducing HRT $_{\mathrm{CM}}$ by added water enhanced the biogas production performance of the digester at a constant high OLR. For the process stability, the $\mathrm{pH}$ in the reactor remained stable with an average of 7.9, which was consistent with the growth environment and activity of methanogenic bacteria (Zhang et al., 2015); the TVFA/TIC ratio was found to be lower than the failure limit (0.3-0.4) value (Rieger and Weiland, 2006). In addition, the single-VFA showed a tend of " $U$ " style curve, which initially fell at $\mathrm{HRT}_{\mathrm{CM}}$ of 30-45 days and the TVFA concentration was lower than $1000 \mathrm{mg} / \mathrm{L}$ at day 130, followed by a slight increase in VFA concentration with continuous decreasing $\mathrm{HRT}_{\mathrm{CM}}$ (Fig. 4). This finding indicated that the process was stable and the inhibition caused by TAN was blocked with reduced $\mathrm{HRT}_{\mathrm{CM}}$ (45-30 days) by adding water. Slight instability was observed again in terms of the accumulation of VFA (acetic, propionic, iso-butyric, and iso-valeric acids) at $\mathrm{HRT}_{\mathrm{CM}}$ of 20 days.

\subsection{Performance of methane fermentation at period III}

As $\mathrm{HRT}_{\mathrm{CM}}$ continued to reduce, the methane fermentation performance exhibited serious deterioration. The SBP at $\mathrm{HRT}_{\mathrm{CM}}$ of 10 and 5 days was 335.8 and $244.5 \mathrm{mg} / \mathrm{L}$, respectively, which

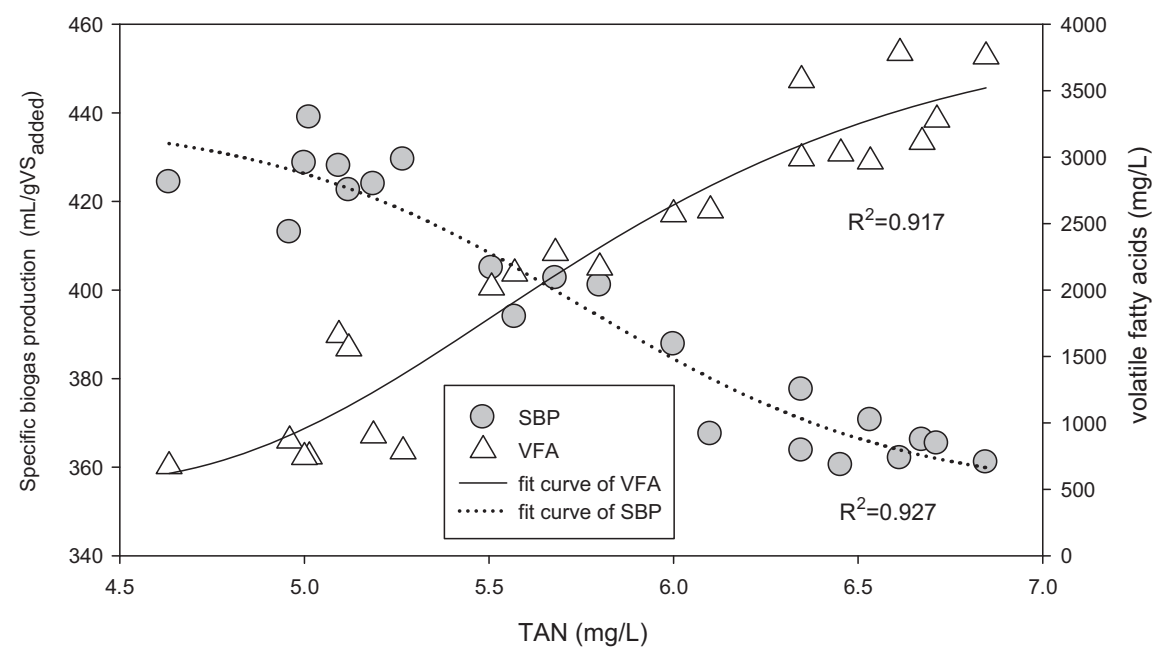

Fig. 5. Specific biogas production (SBP) and volatile fatty acids (VFA) as function of TAN. 
accounted for only $79.5 \%$ and $57.9 \%$ of the theoretical biogas production potential of $\mathrm{CM}(422.4 \mathrm{mg} / \mathrm{L})$ achieved by batch test, respectively. Nie et al. (2015) reported that the doubling time of some methanogens was suggested to be 10 days or more. In this study, as $\mathrm{HRT}_{\mathrm{CM}}$ reduced to 10 and 5 days, the $\mathrm{HRT}_{\text {total }}$ decreased to 3-5 days accordingly, which caused the washout of methanogens, then the methane production was blocked. Meanwhile, the acid-base equilibrium system was broken, and the $\mathrm{pH}$ dropped sharply from 7.9 to 7.2 , which was accompanied with an increase in the VFA concentration. The increase in VFA also corresponded to the changes in the VFA/TIC ratio, which exceeded the threshold value of 0.4 during this period ( $\mathrm{HRT}_{\mathrm{CM}}: 10-5$ days). At $\mathrm{HRT}_{\mathrm{CM}}$ of 5 days ( $\mathrm{HRT}_{\text {total }}$ : 30 days), the acetic and propionic acids were remarkably accumulated to over 6000 and $1000 \mathrm{mg} / \mathrm{L}$, respectively. In contrast to phase I-b, excluding the iso-butyric $(>200 \mathrm{mg} / \mathrm{L})$ and iso-valeric acids ( $>300 \mathrm{mg} / \mathrm{L}$ ), butyric acid was also significantly observed in phase III. This result indicated that the VFA degradation efficiencies in phase III were even poorer than that in phase I. In addition, the easily degradable n-butyrate and n-valerate in phase I were not able to be instantly degraded in phase III which caused the further accumulation in this phase. In phase I-b $\left(\mathrm{HRT}_{\mathrm{CM}}\right.$ : 52 days), the accumulation of VFA was due to the high concentration of ammonia, which decreased methanogenic activity. Nevertheless, at $\mathrm{HRT}_{\mathrm{CM}}$ of 5 days, the TAN decreased sharply to lower than $3000 \mathrm{mg} / \mathrm{L}$ because of the following reasons: (1) the increasing dilution of substrate with distilled water with reducing the $\mathrm{HRT}_{\mathrm{CM}}$; and (2) less protein degradation and a higher incorporation of ammonia by the microorganisms at a low HRT total $_{\text {(Schmidt }}$ et al., 2014). Hence, excess washout of methanogens interrupting the carbon flow through to methane may be the main limiting factor for buildup of the VFA under short $\mathrm{HRT}_{\mathrm{CM}}$ (10-5 days) conditions (Borja et al., 2002). These findings confirmed that the HRT influenced the pathway of acetate conversion to methane in AD process (Westerholm, 2012). The results from this laboratoryscale CSTR study also verified that the HRT total was a crucial factor in avoiding washout of the microbes and maintaining stable methane fermentation performance.

\subsection{Kinetics evaluation}

\subsubsection{Substrate balance model}

Using a substrate balance model to examine the organic matters (COD or VS) balance during the AD process had been described by previous studies (Borja et al., 2002; Borja et al., 2004a; Borja et al., 2004b; Guo et al., 2013). According to the substrate mass balance model and the results of $\mathrm{AD}$ of $\mathrm{CM}$ at a constant OLR with a reduction of $\mathrm{HRT}_{\mathrm{CM}}$, the VS conversion process could be given by the following Eqs. (5) and (6) (Borja et al., 2002):

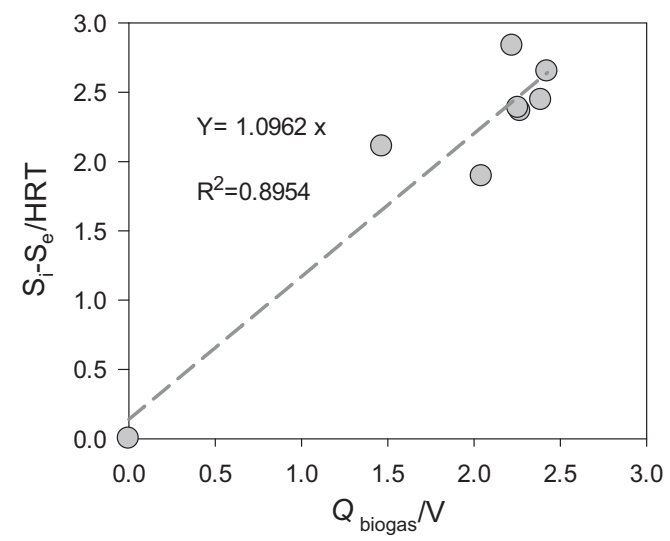

$Q S_{i}=Q S_{e}+q_{\text {biogas }} \cdot Y_{S / G}$

and

$Q S_{i}=Q S_{e}+q_{\mathrm{CH} 4} \cdot Y_{S / M}$

where $\mathrm{Q}$ is the flow rate $(\mathrm{L} / \mathrm{d}) ; \mathrm{S}_{\mathrm{i}}$ is the VS concentration in the influent $(\mathrm{g} / \mathrm{L})$; Se is the VS concentration in the effluent $(\mathrm{g} / \mathrm{L}) ; \mathrm{q}_{\text {biogas }}$ is daily biogas production $(\mathrm{L} / \mathrm{d}) ; \mathrm{q}_{\mathrm{CH} 4}$ is daily methane production $(\mathrm{L} / \mathrm{d}) ; \mathrm{Y}_{S / G}$ is the conversion coefficient of substrate into biogas $\left(\mathrm{gVS}_{\text {removed }} / \mathrm{L}\right.$ ) and $\mathrm{Y}_{S / M}$ is the conversion coefficient of substrate into $\mathrm{CH}_{4}\left(\mathrm{gVS}_{\text {removed }} / \mathrm{L}\right)$.

Dividing by the effective volume $\mathrm{V}(\mathrm{L})$ of the digester, then the grouping terms in Eqs. (5) and (6) could give two new Eqs. (7) and (8):

$\frac{S_{i}-S_{e}}{H R T}=Y_{S / G} \cdot \frac{q_{\text {biogas }}}{V}$

and

$\frac{S_{i}-S_{e}}{H R T}=Y_{S / M} \cdot \frac{q_{C H 4}}{V}$

According to Eqs. (7) and (8), if (Si-Se)/HRT is plotted against to $\mathrm{q}_{\text {biogas }} / \mathrm{V}$ and $\mathrm{q}_{C H 4} / \mathrm{V}, \mathrm{Y}_{S / G}$ and $\mathrm{Y}_{S / M}$ can be obtained as the slope of a straight line. As shown in Fig. 6, $Y_{S / G}$ and $Y_{S / M}$ were 1.096 $\mathrm{gVS}_{\text {removed}} / \mathrm{L}$ biogas and $1.787 \mathrm{gVS}$ removed $/ \mathrm{L} \mathrm{CH}_{4}$, respectively. Based on this slope coefficient, the biogas and methane yield coefficients were calculated to be $0.912 \mathrm{~L}$ biogas/gVS removed and $0.560 \mathrm{~L}$ $\mathrm{CH}_{4} / \mathrm{gVS}_{\text {removed, }}$ respectively. The methane yield coefficients in this study was comparable with the result observed by Guo et al. (2013), who reported that the methane potential of pig manure at $38{ }^{\circ} \mathrm{C}$ was $0.587 \mathrm{~L} \mathrm{CH}_{4} / \mathrm{gVS}_{\text {removed. }}$.

\subsubsection{Sludge yield coefficient}

For $1 \mathrm{~mol}$ of $\mathrm{CH}_{4}$ emitted (22.4 L at STP), 2 mol of oxygenequivalents COD are destroyed (64 g) (Guo et al., 2013; Tao et al., 2015). According to this result, $2.86 \mathrm{~g}$ of COD destruction at STP is equivalent to $1 \mathrm{~L}$ of $\mathrm{CH}_{4}$ production. Therefore, $1 \mathrm{~g}$ VS is equivalent to $1.60 \mathrm{~g}$ COD, which is similar to the value of $1.68 \mathrm{~g}$ COD reported by Guo et al. (2013). Generally, the COD removed in methane fermentation has two transform paths, with some COD used for cell synthesis and some for the production of $\mathrm{CH}_{4}$ (Borja et al., 2002; Qiang et al., 2012). This model has been used to estimate the sludge yield in the $\mathrm{AD}$ process of pig manure (Guo et al., 2013), food waste (Shin et al., 2001a; Zhang et al., 2015), and landfill leachate (Chen et al., 2008a; Timur and Özturk, 1999). When VMPR was plotted against volumetric COD removal rate (Fig. 7), the VMPR increased with COD removal at a rate of

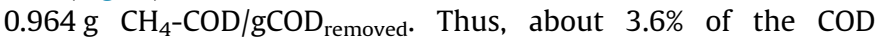

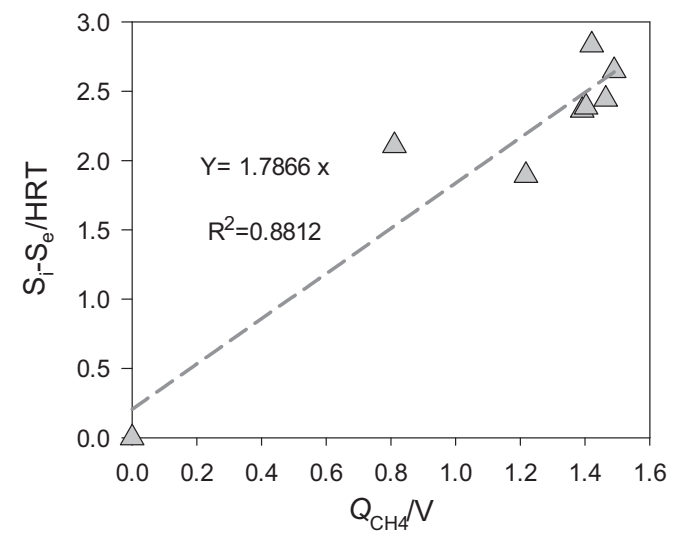

Fig. 6. Variation in the $\left(S_{i}-S_{e}\right) / H R T$ as a function of volumetric biogas production and volumetric methane production. 


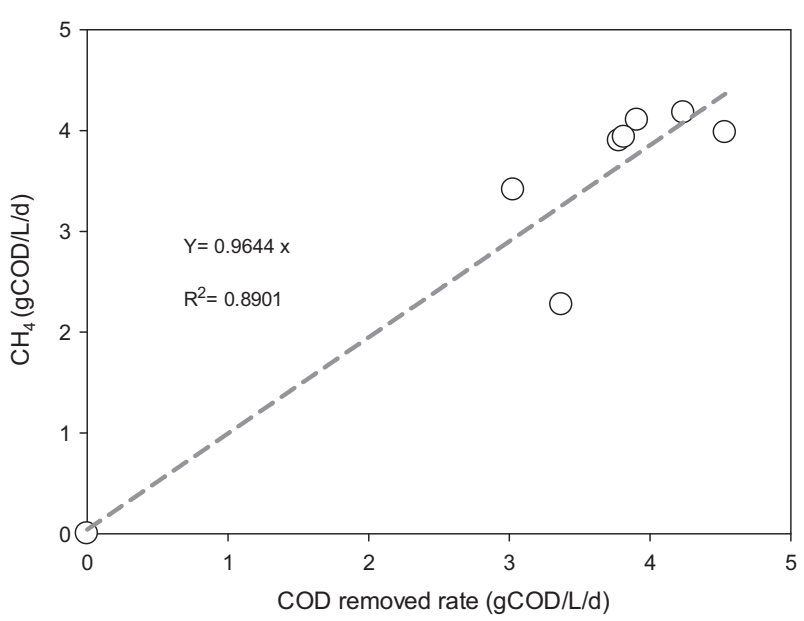

Fig. 7. Volumetric methane production rate (VMPR) as a function of volumetric COD removal rate $(\mathrm{g} \mathrm{COD} / \mathrm{L} / \mathrm{d})$.

removed was converted to biomass. The COD equivalence of the biomass in the digester was $1.41 \mathrm{~g}$ COD/gVSS (Guo et al., 2013), based on the biomass structural formula of $\mathrm{C}_{5} \mathrm{H}_{7} \mathrm{O}_{2} \mathrm{~N}$. The calcu-

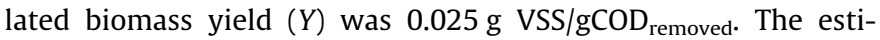
mated sludge yield in the present study was of the same order of magnitude as the $0.02-0.12 \mathrm{~g} \mathrm{VSS} / \mathrm{gCOD}_{\text {removed }}$ reported by other researchers who used this method (Table 3 ).

\subsubsection{Biomass balance}

The net microbial growth rate can be evaluated based on the biomass balance equation as described by Guo et al. (2013):

$\frac{d X}{d t} V=Q X_{0}-Q X+r_{g}^{\prime} V$

where $V$ is the effective volume of the digester $(\mathrm{L}), Q$ is flow rate of influent $(\mathrm{L} / \mathrm{d}), X_{0}$ is microbial concentration in influent $(\mathrm{g} / \mathrm{L}), X$ is microbial concentration in effluent $(\mathrm{g} / \mathrm{L})$ and $r_{g}{ }^{\prime}$ is net microbial growth rate $(\mathrm{g} / \mathrm{L} / \mathrm{d})$.

The $r_{g}{ }^{\prime}$ in Eq. (9) could be expressed by the following equation:

$r_{g}^{\prime}=\frac{\mu_{\max } S X}{K_{s}+S}-K_{d} \cdot X=\frac{Y K S X}{K_{s}+S}-K_{d}$

where $\mu_{\max }$ is the microbial maximum specific growth rate $\left(\mathrm{d}^{-1}\right), \mathrm{S}$ is the concentration of the growth-limiting substrate $(\mathrm{g} / \mathrm{L}), K_{s}$ is the half rate constant $(\mathrm{g} / \mathrm{L})$ and $\mathrm{K}_{\mathrm{d}}$ is endogenous decay coefficient $\left(\mathrm{d}^{-1}\right)$.

As reported by Guo et al. (2013), under the steady state of a CSTR, the $\mathrm{dX} / \mathrm{dt}=0$ and concentration of biomass in the influent is very small and negligible $\left(\mathrm{X}_{0}=0\right)$, then the microorganism concentration in the digester can be described as:

$X=\frac{Y\left(S_{i}-S\right)}{1+K_{d} \theta_{c}}$

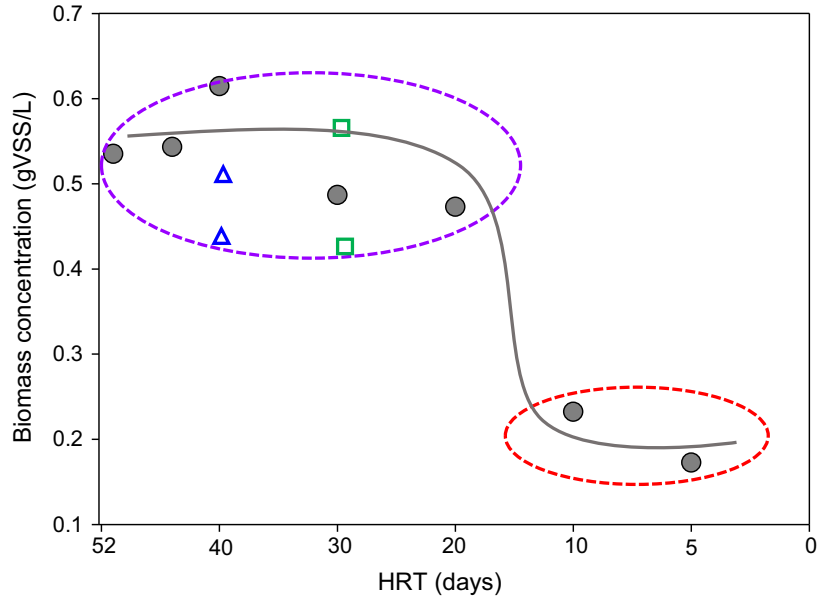

Fig. 8. Variation in the calculated biomass concentration as a function of $\mathrm{HRT}_{\mathrm{CM}}$. this study, $\Delta$ (Zhang et al., 2014), $\square$ (Guo et al., 2013)).

where $S_{i}$ is the influent substrate concentration $(\mathrm{g} / \mathrm{L})$ and $\theta_{\mathrm{c}}$ is $\mathrm{HRT}_{\text {liqiud }}$ (the mean cell retention time (MCRT) or sludge retention time (SRT) equals to the HRT $_{\text {liqiud }}$ in the stable CSTR).

Following Eq. (11), the biomass concentration under different HRT conditions can be calculated using $\mathrm{Y}$ and $\mathrm{K}_{\mathrm{d}}$ : $0.03 \mathrm{~d}^{-1}$ (Guo et al., 2013). Fig. 8 shows that the biomass concentration decreased with reducing of HRT. Similar to the found of Guo et al. (2013) and Zhang et al. (2015), as HRT $_{\mathrm{CM}}$ over 20 days, the biomass concentration maintained in a range of $0.473-0.615 \mathrm{gVSS} / \mathrm{L}$, but which dropped notably to $0.173 \mathrm{gVSS} / \mathrm{L}$ at $\mathrm{HRT}_{\mathrm{CM}}$ of 5 days. This indicated that much more microbiology was washed out at short $\mathrm{HRT}_{\mathrm{CM}}(10$ 5 days) and this also the main reason for low methane production and poor performance while $\mathrm{HRT}_{\mathrm{CM}}$ decreased to 10-5 days. However, the concentrations observed in this study were much lower than the ranges reported in previous studies (10-23 gVSS/L) (Karim et al., 2007; Lawrence and McCarty, 1970). This also confirmed the observation by Lawrence and McCarty (1970), who pointed out that for non-soluble wastes, the biomass concentration can be one or two orders of magnitude higher in anaerobic digesters based on VSS.

\section{Conclusions}

The reduce in $\mathrm{HRT}_{\mathrm{CM}}$ relaxed the inhibition of ammonia nitrogen and improved methane fermentation performance at constant

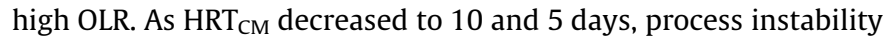
was observed with a high TVFA/TIC ratio $(>0.4)$ due to the excess biomass washout. At $\mathrm{HRT}_{\mathrm{CM}}$ of 5 days, the SBP dropped to $244.5 \mathrm{~mL} / \mathrm{gVS}_{\text {added, }}$, and the acetic and propionic acid contents climbed sharply to over 6000 and $1000 \mathrm{mg} / \mathrm{L}$, respectively. The biomass balance model revealed that short $\mathrm{HRT}_{\mathrm{CM}}$ (5-10 days) caused

Table 3

Comparison of sludge yield (Y) from different kinds of substrates and fermentation conditions.

\begin{tabular}{|c|c|c|c|}
\hline Substrate & Fermentation conditions & $\mathrm{Y}\left(\mathrm{gVSS} / \mathrm{gCOD}_{\text {removed }}\right)$ & References \\
\hline Pig manure & $28^{\circ} \mathrm{C}, \mathrm{CSTR}, \mathrm{HRT}=25 \mathrm{~d}$ & 0.065 & Guo et al. (2013) \\
\hline Pig manure & $38^{\circ} \mathrm{C}, \mathrm{CSTR}, \mathrm{HRT}=25 \mathrm{~d}$ & 0.016 & Guo et al. (2013) \\
\hline Landfill leachate & $35^{\circ} \mathrm{C}, \mathrm{ASBR}, \mathrm{HRT}=1.5-10 \mathrm{~d}$ & 0.12 & Timur and Özturk (1999) \\
\hline Landfill leachate & $35^{\circ} \mathrm{C}, \mathrm{AMBBR}, \mathrm{HRT}=4 \mathrm{~d}$ & 0.054 & Chen et al. (2008a) \\
\hline Food waste & $37^{\circ} \mathrm{C}$, UASB & 0.057 & Shin et al. (2001b) \\
\hline Food waste & $37^{\circ} \mathrm{C}, \mathrm{CSTR}, \mathrm{HRT}=40 \mathrm{~d}$ & 0.023 & Zhang et al. (2015) \\
\hline Food waste & $37^{\circ} \mathrm{C}, \mathrm{CSTR}, \mathrm{HRT}=40 \mathrm{~d}$ & 0.051 & Zhang et al. (2015) \\
\hline $\mathrm{CM}$ & $38^{\circ} \mathrm{C}, \mathrm{CSTR}, \mathrm{HRT}=52-5 \mathrm{~d}$ & 0.025 & This study \\
\hline
\end{tabular}

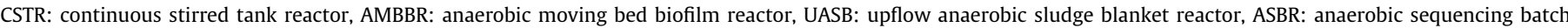
reactor. 
an excess washout of microorganisms, which dropped by 2.5 times than that at $\mathrm{HRT}_{\mathrm{CM}}$ of 20-52 days. This phenomenon could be the main reason for process failure.

\section{Acknowledgements}

This study was supported by the Non-Profit Research Foundation for Agriculture (Grant No. 201303091), and China Agriculture Research System (Grant No. CARS-36-10B). This study was also supported by the Federal Ministry of Food, Agriculture and Consumer Protection (BMELV). The authors alsso thank Dr. Xin Li, Bärbel Haase and Susann Hoffmann for the assistance in reactor operation and analytic.

\section{References}

Anthonisen, A., Loehr, R., Prakasam, T., Srinath, E., 1976. Inhibition of nitrification by ammonia and nitrous acid. Journal (Water Pollution Control Federation), 835852.

APHA, 2005. Standard Methods for the Examination of Water and Wastewater. American Public Health Association (APHA), Washington, DC, USA.

Borja, R., González, E., Raposo, F., Millán, F., Martín, A., 2002. Kinetic analysis of the psychrophilic anaerobic digestion of wastewater derived from the production of proteins from extracted sunflower flour. J. Agric. Food Chem. 50, 4628-4633.

Borja, R., Rincón, B., Raposo, F., Domınguez, J., Millán, F., Martın, A., 2004. Mesophilic anaerobic digestion in a fluidised-bed reactor of wastewater from the production of protein isolates from chickpea flour. Process Biochem. 39, 1913-1921.

Borja, R., Rincón, B., Raposo, F., Sánchez, E., Martın, A., 2004. Assessment of kinetic parameters for the mesophilic anaerobic biodegradation of two-phase olive pomace. Int. Biodeter. Biodegr. 53, 71-78.

Chen, S., Sun, D., Chung, J.-S., 2008a. Simultaneous removal of COD and ammonium from landfill leachate using an anaerobic-aerobic moving-bed biofilm reactor system. Waste Manage. 28, 339-346.

Chen, Y., Cheng, J.J., Creamer, K.S., 2008b. Inhibition of anaerobic digestion process: a review. Biores. Technol. 99, 4044-4064.

Climenhaga, M., Banks, C., 2008. Anaerobic digestion of catering wastes: effect of micronutrients and solids retention time. Water Sci. Tecnol. 57, 687-692.

Dalkılıc, K., Ugurlu, A., 2015. Biogas production from chicken manure at different organic loading rates in a mesophilic-thermopilic two stage anaerobic system. J. Biosci. Bioeng. 120, 315-322.

Dareioti, M.A., Kornaros, M., 2014. Effect of hydraulic retention time (HRT) on the anaerobic co-digestion of agro-industrial wastes in a two-stage CSTR system. Biores. Technol. 167, 407-415.

Di Maria, F., Sordi, A., Cirulli, G., Micale, C., 2015. Amount of energy recoverable from an existing sludge digester with the co-digestion with fruit and vegetable waste at reduced retention time. Appl. Energ. 150, 9-14.

Güelfo, L.F., Álvarez-Gallego, C., Márquez, D.S., García, L.R., 2013. Destabilization of an anaerobic reactor by wash-out episode: effect on the biomethanization performance. Chem. Eng. J. 214, 247-252.

Gerber, M., Span, R., 2008. An analysis of available mathematical models for anaerobic digestion of organic substances for production of biogas. In: Proc. IGRC, Paris.

Ghaly, A., Sadaka, S., Hazza'a, A., 2000. Kinetics of an intermittent-flow, continuousmix anaerobic reactor. Energy Sources 22, 525-542.

Guo, J., Dong, R., Clemens, J., Wang, W., 2013. Kinetics evaluation of a semicontinuously fed anaerobic digester treating pig manure at two mesophilic temperatures. Water Res. 47, 5743-5750.

Jaxybayeva, A., Yangin-Gomec, C., Cetecioglu, Z., Ozbayram, E.G., Yilmaz, F., Ince, O. 2014. Bioenergy production from diluted poultry manure and microbial consortium inside Anaerobic Sludge Bed Reactor at sub-mesophilic conditions. J. Environ. Sci. Heal., Part B 49, 775-785.
Karim, K., Klasson, K.T., Drescher, S.R., Ridenour, W., Borole, A.P., Al-Dahhan, M.H., 2007. Mesophilic digestion kinetics of manure slurry. Appl. Biochem. Biotech. $142,231-242$

Kukkonen, T., 2014. Anaerobic Dry Fermentation of Dried Chicken Manure and Kitchen Waste. University of Jyväskylä, Master's Theses.

Lawrence, A.W., McCarty, P.L., 1970. Unified basis for biological treatment design and operation. J. Sanit. Eng. Div. 96, 757-778.

Matthies, C., Schink, B., 1992. Reciprocal isomerization of butyrate and isobutyrate by the strictly anaerobic bacterium strain WoG13 and methanogenic isobutyrate degradation by a defined triculture. Appl. Environ. Microbiol. 58, 1435-1439.

Mosey, F., 1983. Mathematical modelling of the anaerobic digestion process: regulatory mechanisms for the formation of short-chain volatile acids from glucose. Water Sci. Technol. 15, 209-232.

Nie, H., Jacobi, H.F., Strach, K., Xu, C., Zhou, H., Liebetrau, J., 2015. Monofermentation of chicken manure: ammonia inhibition and recirculation of the digestate. Biores. Technol. 178, 238-246.

Niu, Q., Qiao, W., Qiang, H., Hojo, T., Li, Y.-Y., 2013. Mesophilic methane fermentation of chicken manure at a wide range of ammonia concentration: stability, inhibition and recovery. Biores. Technol. 137, 358-367.

Otero, M., Lobato, A., Cuetos, M., Sánchez, M., Gómez, X., 2011. Digestion of cattle manure: thermogravimetric kinetic analysis for the evaluation of organic matter conversion. Biores. Technol. 102, 3404-3410.

Qiang, H., Lang, D.-L., Li, Y.-Y., 2012. High-solid mesophilic methane fermentation of food waste with an emphasis on iron, cobalt, and nickel requirements. Biores. Technol. 103, 21-27.

Rieger, C., Weiland, P., 2006. Prozessstörungen frühzeitig erkennen. Biogas J. 4, 18 20.

Schmidt, T., Ziganshin, A.M., Nikolausz, M., Scholwin, F., Nelles, M., Kleinsteuber, S. Pröter, J., 2014. Effects of the reduction of the hydraulic retention time to 1.5 days at constant organic loading in CSTR, ASBR, and fixed-bed reactorsperformance and methanogenic community composition. Biomass Bioenerg. 69, 241-248.

Shin, H., Han, S., Song, Y., Lee, C., 2001a. Performance of UASB reactor treating leachate from acidogenic fermenter in the two-phase anaerobic digestion of food waste. Water Res., 3441-3447

Shin, H., Han, S., Song, Y., Lee, C., 2001b. Performance of UASB reactor treating leachate from acidogenic fermenter in the two-phase anaerobic digestion of food waste. Water Res. 35, 3441-3447.

Tao, H.C., Zhang, H.R., Li, J.B., Ding, W.Y., 2015. Biomass based activated carbon obtained from sludge and sugarcane bagasse for removing lead ion from wastewater. Biores. Technol. 192, 611-617.

Thauer, R.K., Kaster, A.-K., Seedorf, H., Buckel, W., Hedderich, R., 2008. Methanogenic archaea: ecologically relevant differences in energy conservation. Nat. Rev. Microbiol. 6, 579-591.

Timur, H., Özturk, I., 1999. Anaerobic sequencing batch reactor treatment of landfill leachate. Water Res. 33, 3225-3230.

VDI, 2006. 4630: Fermentation of organic materials, characterisation of the substrate, sampling, collection of material data, fermentation tests. Verein Deutscher Ingenieure (VDI), editor. VDI Handbuch Energietechnik. Berlin: Beuth Verlag GmbH, 44-59.

Wei, Q., Zhang, W., Guo, J., Wu, S., Tan, T., Wang, F., Dong, R., 2014. Performance and kinetic evaluation of a semi-continuously fed anaerobic digester treating food waste: effect of trace elements on the digester recovery and stability. Chemosphere 117, 477-485.

Westerholm, M., 2012. Biogas Production Through the Syntrophic AcetateOxidising Pathway: Characterization and Detection of Syntrophic AcetateOxidising Bacteria. Swedish University of Agricultural Sciences, Uppsala.

Yenigün, O., Demirel, B., 2013. Ammonia inhibition in anaerobic digestion: a review. Process Biochem. 48, 901-911.

Zhang, W., Lang, O., Wu, S., Li, W., Bah, H., Dong, R., 2014. Anaerobic digestion characteristics of pig manures depending on various growth stages and initial substrate concentrations in a scaled pig farm in Southern China. Biores. Technol. 156, 63-69.

Zhang, W., Wu, S., Guo, J., Zhou, J., Dong, R., 2015. Performance and kinetic evaluation of semi-continuously fed anaerobic digesters treating food waste: role of trace elements. Biores. Technol. 178, 297-305. 